\title{
THE STUDENTS' SELF-DIRECTED LEARNING IN ENGLISH FOREIGN LANGUAGE CLASSES DURING THE COVID-19 PANDEMIC
}

\author{
Savitri Dwilestari ${ }^{1 *}$, Ahmad Zamzam², Ni Wayan Mira Susanti ${ }^{3}$, Edy Syahrial $^{4}$ \\ University of Mataram \\ *e-mail: savitridwilestari@gmail.com
}

\begin{abstract}
The success of learning cannot be separated from the level of self-directed learning (SDL) of the students. Therefore, this study aims at describing the level of EFL learners' self-directed learning and exploring the main factors which affect their SDL levels. The method used in this study is descriptive qualitative research. The participants are the fourth-semester students of the English Education Program in higher education in Lombok. The data were collected by using two sets of questionnaires: a close-ended questionnaire and an open-ended questionnaire. The data were analyzed with a thematic analysis method. The findings showed that $60 \%$ of students are at moderate level, $33 \%$ high, and $1 \%$ in low level. Two main factors which affect students' SDL levels are teacher-student interaction and intrinsic motivation.
\end{abstract}

Keywords: self-directed learning (SDL), SDL levels, self-directed learning factors

\section{INTRODUCTION}

Self-directed learning which is known as SDL is a critical problem that can help students develop the insight that they need to success in the learning process. Knowles (1975) described SDL as a phase where people identify their learning requirements, determine their learning objectives, decide their human and mental resources for study, select and apply their effective strategies for study, and assess their learning outcome with or without the support of others. This may imply that this learning strategy aims to teach the individual self-control and selfmanagement for reaching the success. Each individual will assess what (s)he needs to develop his/her abilities and determine the learning process and outcomes. Therefore, it is reasonable to state that self-directed learning (SDL) is so important because it enables a person to adapt quickly to new environments and situations, to gather resources, solve new problems or deal with situations that (s)he encounters.

Furthermore, Song \& Hill (2007) stated that self-directed learning practice is not limited to certain educational places such as formal schools and universities. Many self-directed learners are those taking online courses and those conducting their own learning projects. So, self-directed learning encompasses not just what we do in formal institutions, but also what students do outside of the classroom to achieve their learning goals when they are unable to attend classroom meetings. Students determine what and how they will learn, with or without the help of the teacher. It can be performed in a group or on an individual basis.

According to Gharti (2019), selfdirected learning is a driving factor that makes students become autonomous learners. $\mathrm{He}$ also defined learning autonomy as the ability of students to understand and effectively regulate their own learning process. Furthermore, to be an autonomous learner by having self-directed learning skills is important for students in the learning process. Khotimah, Widiati, Mustofa, and Ubaidillah, (2019) implied that successful learners are progressively seen as individuals that are capable to conceptualize knowledge from the world experiences directly instead of those who responds to the instruction well.

During the Covid-19 pandemic like nowadays conditions, the face-to-face learning process was reduced to minimize the spread of the coronavirus which makes the learning system diverted through online. Learning with the online system takes place by utilizing various online 
learning features such as google classroom, google meet, zoom meeting and various other types of websites. These conditions, of course, create a significant difference in the world of education. However, there are common obstacles faced by students during online learning, including the inadequate internet network to access the materials provided by lecturers. This statement is supported by a study from Mubarokah \& Sahara (2021) who stated that the most difficulties that students face during the online learning is the internet connection or signal. Almost all of the students answer that they have unstable internet connection, so they cannot follow the class smoothly. This problem caused the lack of understanding material for students and it made online learning ineffective.

Furthermore, according to Coman (2020) the most critical issues in online learning are technological issues, accompanied by teachers' lack of technical skills and poorly adapted teaching styles to online learning. Then the materials conveyed by lecturers through online learning are more difficult to understand because students cannot interact directly with their lecturers. The indirect interaction method has limitations in the discussion so that students feel less and difficult to understand the materials given. Students felt lower learning satisfaction and more difficult communication either with instructors or with peer students in doing the distance learning (Amir et al., 2020).

Because of the many problems that arise in online learning, students cannot learn optimally in the normal conditions in the classroom as before the pandemic where they are free to interact with their lecturers in class. Ahmad (2016) stated that online learning experienced many obstacles when applied. Therefore, if there is no awareness of SDL in students to study at home, they will be left behind and do not understand the material that should be mastered to achieve the learning objectives. Garrison (1997) states that students who have a high awareness of SDL show a greater awareness of responsibility as learners. With SDL awareness in students, it can make learning more valuable and they can monitor themselves in the learning process. Students will be curious in their learning and willing to attempt new things, see problems as challenges, want changes to be better, and enjoy every process of learning. SDL, according to Morrow (1993), can allow students to build their own rules and leadership patterns with adequate preparation and implementation. It can be meant that SDL can be interpreted as allowing students to become more successful learners and more creative in their learning.

Humaira \& Hurriyah (2018) stated that students who only depend on the teacher in their class tend to lag behind and are slower in achieving learning outcomes. She also stated that due to limited time in class, students are encouraged to take responsibility for their own learning and learn independently outside the classroom which is called self-directed learning (SDL). So in the current conditions of online learning, students are expected to be more aware, controlled, independent, and active in their own learning at home to cover the deficiencies that exist in the online learning process in order to achieve optimal learning goals.

Williamson (2007) stated that depending on their ability, each student has a different level of SDL. There are several ranges that can be used to describe the degree of students' SDL levels. He proposed SDL levels categorization into three levels. The first level of students with high SDL, the second level of students with moderate SDL, and the third level of students who have low SDL. The higher the SDL levels of students, the more likely they are to be able to figure out how to solve problems that they encounter during the learning process. Therefore, it is necessary to assess students' SDL levels in order to raise student awareness of the importance of SDL to increase their ability in solving 
problems that exist during their learning process.

Many previous studies which have talked about the same topic in the range of SDL, they are mostly focused on students' motivation in SDL, factors that influence students' SDL and students' perception on SDL. Therefore, the researchers are interested in finding the students main factors which affect them in SDL especially based on Huang (2008) because it has not been conducted in the context of Indonesian students before and the researcher is also interested in measuring the students level in SDL.

Furthermore, there is a research study which is quite similar to this research study because it also investigated the students' level of self-directed learning. It is a research which was conducted by Ummah \& Huriyah (2016) entitled "Selfdirected learning of Senior High School Students in Learning English at Home School Pena". The other purpose of this study was to learn about the different types of self-directed learning activities that students engage in, as well as their SDL skills and their barriers to SDL at home school Pena. This research used questionnaires and interviews as the instruments. In addition, SDL in this research was implemented in senior high school students at home school Pena. However, she did not investigate the factors that affect students' SDL levels. In order to fill the gaps in the previous literature on SDL, the researchers conducted a study on SDL levels and discovered factors that affect students' SDL levels and also this study has been conducted on university students.

Based on the descriptions above, the researcher is interested in measuring students' self-directed learning levels by using the self-rating scale of SDL questionnaire or it known as SRSSDL questionnaire which is adopted from Williamson (2007) theory. The higher the SDL levels of students, the more likely they are to be able to figure out how to solve problems. Therefore, it is necessary to assess students' SDL levels in order to raise student awareness of the value of SDL in order to increase their ability to solve problems that exist during their learning process and also this study is expected to find out what the main factors which affect students' SDL levels in English Education Program at University of Mataram.

\section{RESEARCH METHODS}

In this research, the researchers used a descriptive qualitative research method. The descriptive qualitative research method in the form of case study suited this research because it describes the students' SDL in English Education Program at University of Mataram. The participants involved in this research were fifteen students from the fourth semester who enrolled in an academic writing course at University of Mataram. The reason the researchers took the academic writing course students as the participant in this study is because of the COVID-19 pandemic, most lecturers implemented online teaching and learning. Especially, most of the learners who are in an academic writing course. To collect the data, the researchers used two types of questionnaires: a close-ended questionnaire in the form of the SRSSDL (The Self Rating Scale of Self-Directed Learning) questionnaire and an open-ended questionnaire. In this research, the data analysis technique employed by the researchers is thematic analysis. It can be divided into six steps. They are familiarizing with the data, generating initial codes, searching for themes, reviewing themes, defining and naming themes, and producing the report.

\section{RESULTS AND DISCUSSION}

Table 1 and 2 show that there are three levels of students' in SDL. They are high SDL level, moderate SDL level and low SDL level. Between the 15 participants of this research, there are 9 students or $60 \%$ of the students who are indicated as 
moderate in SDL levels and the rest of students get high and low in SDL levels. There are $33 \%$ of the students or 5 students who are indicated as high in SDL levels and there is only one student who indicate as low in SDL levels.

Table 1. The Level of Participants' Self-Directed Learning

\begin{tabular}{ccc}
\hline SDL Level & Number of the Participants & Percentage \\
\hline High & 5 & $33,3 \%$ \\
\hline Moderate & 9 & $60 \%$ \\
\hline Low & 1 & $6,7 \%$ \\
\hline
\end{tabular}

Table 2 Percentages of Students' SDL levels where S: student

\begin{tabular}{|c|c|c|c|c|c|c|c|}
\hline \multirow[t]{2}{*}{ Students } & \multicolumn{5}{|c|}{ Indicator of SDL } & \multirow[t]{2}{*}{ Total } & \multirow[t]{2}{*}{ SDL Level } \\
\hline & Awareness & $\begin{array}{l}\text { Learning } \\
\text { Strategies }\end{array}$ & $\begin{array}{l}\text { Learning } \\
\text { Activities }\end{array}$ & Evaluation & $\begin{array}{l}\text { Interpersonal } \\
\text { Skill }\end{array}$ & & \\
\hline $\mathrm{S} 1$ & 22 & 23 & 17 & 22 & 22 & 106 & Low \\
\hline $\mathrm{S} 2$ & 48 & 47 & 54 & 50 & 42 & 241 & High \\
\hline $\mathrm{S} 3$ & 55 & 54 & 50 & 54 & 52 & 265 & High \\
\hline $\mathrm{S} 4$ & 49 & 44 & 43 & 45 & 36 & 217 & Moderate \\
\hline S5 & 46 & 53 & 44 & 53 & 49 & 245 & High \\
\hline S6 & 28 & 38 & 33 & 34 & 35 & 168 & Moderate \\
\hline S7 & 45 & 42 & 48 & 50 & 42 & 227 & High \\
\hline S8 & 54 & 49 & 47 & 49 & 50 & 249 & High \\
\hline S9 & 29 & 36 & 36 & 34 & 44 & 179 & Moderate \\
\hline S10 & 38 & 41 & 43 & 45 & 45 & 212 & Moderate \\
\hline $\mathrm{S} 11$ & 41 & 41 & 45 & 45 & 45 & 217 & Moderate \\
\hline S12 & 29 & 22 & 42 & 27 & 40 & 160 & Moderate \\
\hline $\mathrm{S} 13$ & 39 & 37 & 42 & 41 & 43 & 202 & Moderate \\
\hline $\mathrm{S} 14$ & 42 & 40 & 48 & 36 & 43 & 209 & Moderate \\
\hline S15 & 39 & 38 & 39 & 39 & 41 & 196 & Moderate \\
\hline
\end{tabular}

The category that most participants got was the moderate level in SDL, because $60 \%$ of the participants belonged to this category. This indicates that students have the possibility to increase their SDL level to a "high SDL" level. This can be seen from the majority of students' scores. From the total number of 15 students, there are nine of them are categorized as moderate level in SDL which consisted of four students scored above 160 and five students scored above 200. This means that their scores are close to the maximum score at this level, which is 220 . It means that they have the possibility to increase their level from moderate level to high level in self-directed learning.

The researchers used the openended questionnaire to find out what factors affect students' levels of SDL. The results of this questionnaire are from the responses of each student and were analyzed by using thematic analysis to determine student responses to this open-ended questionnaire.
The open-ended questionnaire in this research has five questions that address two aspects of self-directed learning: motivational factors and learning environment factors.

First question is about teacher and student interaction. Most of the participants stated that their lecturer supported them in doing SDL. Because of nowadays condition, most of their interactions and support were done through online. The lecturer usually sends the materials for selfdirected learning via WhatsApp group. Then, the lecturer suggested their students to read the material and try to complete the exercises and if the students have any question about the materials or the exercises they will ask about it through WhatsApp group and the lecturer will answer it there too.

Second question is about the facilitation process. Most of the participants answered and stated that their lecturer gave them clear direction when doing SDL. On 
the other hand, while several of the participants stated that there is no clear direction or they do it by themselves without their lecturers' direction.

Third question is about resources of learning. Most of the participants stated that there are several facilities which their college provided to support them in doing SDL such as free WIFI, the library and some comfortable place to study for doing self-directed learning. On the opposite side, only several of them stated that the college is not very supportive in the facilities. Because of the Covid-19 pandemic, most of the students are more often doing the learning activities at home. Unfortunately, the facilities that have been provided have become unused.

Fourth question is about extrinsic motivation. Most of the participants stated that they have the responsibility to work hard in learning only to achieve the academic results because it is their obligation as learners, while several of them who have the different perception that they think it is not only about the academic result but also it is about the knowledge which they got from learning. They think that the knowledge which they got and can be useful for the future is more important than only the academic result.

Fifth question is about intrinsic motive. Based on the students' answers for this question the researchers found that all of the participants think that an interesting topic can motivate them in doing the selfdirected learning. When they are not interested in the topic of learning, some of them argue that it only puts more pressure but less progress on their learning process. Otherwise, if the learning topic was interesting to them, they would get motivated and they would be driven to learn it.

From the several descriptions above, the researchers concluded the two main factors which affect SDL level of students at University of Mataram, especially in English education program. The two factors are teachers-students' interaction and intrinsic motivation. Because most of them mentioned things related to these two factors. Therefore, the researchers concluded that these two factors were very influential for them in doing SDL.

Personal responsibility is the foundation of SDL. Students who take ownership of their learning are better able to choose appropriate learning activities and learning strategies to meet their learning objectives (Brockett \& Hiemstra 2018). In line with the researchers found in this study, where students with high scores in SDL got the high score in the aspect of learning activities. This means that they carried out in learning activities that required students to actively participate for them to become self-directed in their learning. While Ummah \& Huriyah (2016) found in their study that SDL is very important to achieve progress in learning because SDL is a learning process that requires full initiative on students in learning. Students with a high level in SDL selected more self-directed learning activities while students who implemented less self-directed learning activities are classified into low SDL levels. It also implies that their level of self-directed learning skills is reflected in their SDL activities. Therefore, it is very important for students to choose their own learning strategies and learning activities to achieve their learning goals in doing SDL.

In the aspect of evaluation in SDL, this study found that feedback can be something that can help students in achieving their learning goals. This statement is supported by Bellon (in Onwuagboke et.al., 2018), one of the important aspects of successful learning is suggestion and feedback. It allows learners to comprehend the materials at hand and provides specific instructions about how to enhance their learning. He also stated that feedback may enhance learners' selfawareness, confidence, and passion for learning. It means the constructive criticism in feedback that students get will help them 
learn more. While, according to Hurst et al., (2013) social interaction is very important in SDL. He found that social interaction can improve student learning outcomes because it can improve their knowledge of literacy, teaching, and critical thinking as well as problem solving skills. It can be concluded that good social interaction and helpful feedback can help students to improve their communication and problem-solving skills.

Teacher accessibility is one of the reasons that learners believe as critical to their productivity and satisfaction with their self-management practice. Lack of students' access to teachers can lead to their lack of willingness to practice SDL in their learning (Lizzio \& Wilson 2005). In line with the researchers found in this study, teacher-student interaction during the learning process gives the students an opportunity to better understand the lessons they are getting. In nowadays conditions where learning through the online class is not enough, the teachers should support their students in doing SDL to increase their learning outcome. However, SDL does not suggest that teachers assign full responsibility in the learning process to learners (Lizzio \& Wilson 2005). Teachers help and guide students, but students must do more based on that guidance, and teachers provide their support to help students enhance their skills and knowledge (Munasinghe, Sutha, and Parera 2019). It may imply that teachers play an essential role in the students' SDL process but students ought to be independent and responsible in their own studies. they should take an active role in developing their own abilities and knowledge.

According to Brockett \& Hiemstra (2018), SDL is the mechanism in which a learner takes the main responsibility for the preparation, evaluation, and implementation of the learning process. In line with Caffarella (in Valente 2005) defined SDL as learning in which the student takes the main responsibility for preparing, carrying out, and assessing the learning experiences. It can be concluded that learners have to control how they react to situations in terms of learning. The challenge for teachers is how to develop strategies in supporting their students to achieve a higher SDL level. In addition, Huang (2008) in her study, found that there are four main kinds of support that students need to be motivated for their success in learning, especially in doing self-directed learning. They are timely and constructive suggestions, independent choices, appropriate workload, and clear directions.

Intrinsic motivation has a great impact on students' SDL during the learning process. The researchers found most of the students in this study believed that if the learning topic was interesting to them, they would get motivated and they would be driven to learn it. This is in accordance with Elizabeth \& Paul (2002) which stated that students should have a strong interest in order to be intrinsically motivated in a particular subject or activity. In line with Bodkyn (2015) research which investigated the influence of SDL and the impact of intrinsic motivation on academic achievement in students. The findings of his research revealed that intrinsic motivation and SDL have a substantial positive impact on student success in learning. In addition, intrinsic motivation, and interest with self-directed learning readiness were statistically significant. However, not all motivational factors were positively related to self-directed learning readiness; extrinsic motivation was not related to the level of self-directed learning readiness (Lee, 2014). It can be used to make connections between intrinsic interest and students engaged in their studies. Students' enthusiasm for the subject seems to motivate them to take control of their learning.

\section{CONCLUSION}

Based on the results of the study, $60 \%$ of the students were included into the category of "moderate SDL" level which means students have passed the halfway to become self-directed learners, but they still 
need guidance from their lecturer for the improvement. Furthermore, 33.3\% students are categorized in the "high SDL" level which means some students are already effective in doing SDL, but they still need to maintain their level by identifying strengths and methods to maintain or strengthen their SDL level in the learning process. Lastly, there are only $6,7 \%$ of students who are categorized in "low SDL" level which means the students should receive treatment from their lecturer and require any necessary changes to better their learning process. The categorization of students' SDL levels in this study was based on the results of the SRSSDL (The Self Rating Scale of Self-Directed Learning) questionnaire that had been given to students. On a scale of 60 to 300 which is the standard that has been set in this SRSSDL questionnaire, the student scores ranged from 106 to 264 . It can be concluded, among the total number of 15 participants in this study, the most dominant level obtained by students was the "moderate SDL" level category where there were 9 students who got this category, while 5 of them are included in the "high SDL" level category and only one student is categorized in the "low SDL" level.

Based on the findings in this study, the researchers concludes that there are two main factors that affect students' SDL level in English Education Program at University of Mataram. They are learning environment factors and motivational factors. The learning environment factors include teachers-students' interaction, because most of the participants in this study consider that they had good interactions with lecturers in conducting SDL. The motivational factors include intrinsic motivation, because the majority of the participants in this study consider that they are very motivated when the topic of learning is interesting for them in doing SDL.

After conducting this research and getting the research results, there are some suggestions for students, lecturers and next researchers. First, for the students: students should continue to develop their SDL level. They should also add more SDL activities to increase their results in the learning process. Next, for the lecturers, in the learning process, lecturers need to support their students to develop their SDL skills. Intrinsic motivation is an important factor that affects students' SDL. However, lecturers must take into account students' interest in designing materials to further motivate students in the learning process so that students' SDL levels can increase. They also need to create an atmosphere that enables students to learn optimally. They can organize classes as student-centered classes. Students will be more intrinsically motivated if they are actively participating in their own learning. Last, for the next researchers to develop or look for more factors that are considered to be able to affect the students' in SDL such as mood, health, gender, etc.

\section{REFERENCES}

Ahmad, Samah. (2016). The Flipped Classroom Model to Develop Egyptian EFL Students' Listening Comprehension. English Language Teaching. 9.166. 10.5539/elt.v9n9p166.

Amir, Lisa \& Tanti, Ira \& Maharani, Diah \& Wimardhani, Yuniardini \& Julia, Vera \& Sulijaya, Benso. (2020). Student Perspective of Classroom and Distance Learning During COVID-19 Pandemic in the Undergraduate Dental Study Program Universitas Indonesia. 10.21203/rs.3.rs-42334/v2.

Braun, Virginia \& Clarke, Victoria. (2006). Using thematic analysis in psychology, Qualitative Research in Psychology, 3:2, 77-101, doi: 10.1191/1478088706qp063oa

Brockett, Ralph \& Hiemstra, Roger. (2018). Self-Direction in Adult Learning: Perspectives on Theory, Research, and Practice, 62-64. doi: $10.4324 / 9780429457319$. 
Bodkyn, C. (2015). Self-directed learning, Intrinsic motivation and students performance. West Indies University.Vol. 5, No.2, 79-93.

Coman, C.; Țîru, L.G.; Meseșan-Schmitz, L.; Stanciu, C.; Bularca, M.C. Online Teaching and Learning in Higher Education during the Coronavirus Pandemic: Students' Perspective. Sustainability 2020, $12, \quad 10367$. https://doi.org/10.3390/su1224103 67

Garrison, D.. (1997). Self-Directed Learning: Toward a Comprehensive Model. Adult Education Quarterly ADULT EDUC QUART. 48. 18-33. doi:

10.1177/074171369704800103.

Gharti, L. (2019). Self-Directed Learning for Learner Autonomy: Teachers' and Students' Perceptions. Journal of NELTA Gandaki, 1, 62-73. https://doi.org/10.3126/jong.v1i0.2 4461

Huang, Mei-hui (2008). Factors Influencing Self-directed Learning Readiness amongst Taiwanese Nursing Students (Taiwan : Queensland University of Technology School of Nursing Institute of Health and Biomedical Innovation). Doctoral philosophy Dissertation, 117-147.

Humaira, Silmy \& Hurriyah, Ismi. (2018). Students' Perspectives towards SelfDirected Learning out of Classroom. doi: 10.2991/iconelt17.2018.2.

Hurst, B., Wallace, R., \& Nixon, S. B. (2013). The Impact of Social Interaction on Student Learning. Reading Horizons: A Journal of Literacy and Language Arts, 52 (4). Retrieved from https://scholarworks.wmich.edu/rea ding horizons/vol52/iss $4 / 5$

Khotimah, K., Widiati, U., Mustofa, M., \& Ubaidillah, M. F. (2019). Autonomous English learning:
Teachers' and students' perceptions. Indonesian Journal of Applied Linguistics, 9, 371-381. doi: 10.17509/ijal.v9i2.20234

Knowles, M. (1975). Self directed learning: A guide for learners and teachers. (New York: Association Press, 1975), p.24. Retrieved from http://home.tweny.rr.com/hiemstra/ sdlhdbk.html

Elizabeth A. Linnenbrink \& Paul R. Pintrich (2002) Motivation as an Enabler for Academic Success, School Psychology Review, 31:3, 313-327, doi: $10.1080 / 02796015.2002 .12086158$

Lee, E. H. (2014). Significant motivational factors in self-directed learning (Elementary Korean School, 2014). Thesis.

Lizzio, Alf \& Wilson, Keithia. (2005). Selfmanaged learning groups in higher education: Students' perceptions of process and outcomes. The British journal of educational psychology. $75 . \quad 373-90 . \quad$ doi: $10.1348 / 000709905 X 25355$.

Morrow, Lesley M., Evelyn Sharkey, and William A. Firestone, "Promoting Independent Reading and Writing through Self-Directed Literacy Activities in a Collaborative Setting". Reading Research Report. No. 2, Spring 1993.

Mubarokah, L., \& Sahra, R. A. (2021). The Difficulties of Using Online Platform as a Teaching Media for Student. Conference on English Language Teaching, 1(1), 296-308. Retrieved from http://conferences.iainpurwokerto.a c.id/index.php/celti/article/view/26

Munasinghe, D.S. \& Sutha, Jayaranjani \& Perera, Jami. (2019). A Study of Factors Influences on Self-Directed Learning of Undergraduates (With Special Reference to Sri Lankan Universities).

Onwuagboke, Bede \& Osuala, Rita \& Agoha, Timothy. (2018). 
Continuous Assessment Feedback and Students' Performances in Semester Examinations in a College of Education. American Journal of Educational Research. 6. 688-693. doi: 10.12691/education-6-6-16.

Song, Liyan \& Hill, Janette. (2007). A Conceptual Model for Understanding Self-Directed Learning in Online Environments. Journal of Interactive Online Learning. 6. Retrieved from www.ncolr.org/jiol

Ummah, H. (2016). Self- directed learning of Senior High School Student in
Learning English at Home School Pena. undergraduate thesis UINSA Surabaya. Retrieved from http://digilib.uinsby.ac.id/id/eprint/ 13734

Valente, Janet. (2005). The Role of SelfDirected Learning in Older Adults' Health Care. Retrieved from https://getd.libs.uga.edu/pdfs/valent e_janet_s_200505_edd.pdf

Williamson, Swapna. (2007). Development of a self-rating scale of self-directed learning. Nurse researcher. 14. 6683. doi: 10.7748/nr2007.01.14.2.66.c6022. 